\title{
Placental Insulin-Like Growth Factor-1 Receptor, Protein Kinase B and Mammalian Target of Rapamycin are Downregulated in HIV-1 Positive Women on Antiretroviral Drugs
}

\author{
Winifrida B. Kidima ${ }^{{ }^{*}}$, Gatambwa D. Mukandala ${ }^{1}$, Osiana Leonard ${ }^{1}$ and Daniel Nkungu ${ }^{2}$ \\ ${ }^{I}$ Department of Zoology and Wildlife Conservation, College of Natural and Applied Sciences \\ University of Dar es Salaam, PO Box 35064, Dar es Salaam, Tanzania \\ ${ }^{2}$ Mwananyamala Referral Hospital, Departments of Obstetrics and Gynecology, PO Box 61665, \\ Dar es Salaam, Tanzania \\ E-mails:winikidi@gmail.com; gatambwa@yahoo.com;lukalijr@yahoo.com; \\ dajopenk1@gmail.com
}

Received 2 Aug 2021, Revised 3 Nov 2021, Accepted 6 Nov 2021, Published Dec 2021

DOI: https://dx.doi.org/10.4314/tjs.v47i5.16

\begin{abstract}
HIV-1 and ARV drugs uptake during pregnancy may change placental phenotype during pregnancy affecting fetal growth. We investigated the influence of maternal HIV-1 and ARV drugs on expression of placental genes important for fetus growth. A total $51 \mathrm{HIV}-1$ positives and 46 HIV-1 negative pregnant women were studied. Placental gene expression changes of insulin-like growth factor receptor 1 (IGF-1) R, mammalian target of rapamycin (mTOR), protein kinase B (AKT-1), sodium-coupled neutral amino acid transporters (Slc38a1, Slca38a2, Slc38a4), inhibin A, adrenomedullin and 11 beta-Hydroxysteroid dehydrogenase type (HSD)-2 were assessed by RT-qPCR. There was a significant decrease in mRNA expression of placental IGF-1R, mTOR, and AKT-1 in HIV-1 positive placentas compared to controls ( $\mathrm{p}<0.0001$ ). There was also significant upregulation of an antiangiogenic molecule, inhibin $A$ and downregulation of angiogenic molecule adrenomedullin in HIV-1 positive placenta (all $\mathrm{p}<$ 0.0001). However, the mRNA expression of placental Slc38a1 and Slca38a2 was higher in both HIV-1 positive and negative women delivering LBW babies compared to controls $(\mathrm{p}<0.0001)$. The placental mRNA expression of $11 \beta$-HSD- 2 increased by 17 folds in HIV-1 negative and by 3.8 folds in HIV-1 positive women delivering LBW babies. IGF-1-P13-AKT-1-mTOR signaling pathway is dysregulated in placenta of HIV-1 positive women on ARV drugs. Higher mRNA expression levels of inhibin A and lower levels of adrenomedullin occur in placenta of HIV-1 positive women delivering LBW babies. ARV drugs and HIV-1 may be involved in the disruption of vascular tone of the placenta and therefore placental perfusion.
\end{abstract}

Keywords: Pregnant women, HIV-1, ARV drugs, Placental IGF-1-AKT-1-mTOR signaling, inhibin A, adrenomedullin, amino acid transporters.

\section{Introduction}

Human immunodeficiency Virus (HIV)-1 remains to be an important risk factor for poor pregnancy outcomes in Eastern and Southern Africa where HIV-1 prevalence is at the greatest. A range of poor pregnancy outcomes have been reported among HIV-1 positive pregnant women on antiretroviral therapy.
These include delivering low birth weight (LBW) babies (birth weight $<2,500 \mathrm{~g}$ ), preterm delivery (PTD), fetal growth restriction (FGR), maternal death and spontaneous infant death (Brocklehurst and French 1998, Goldenberg et al. 2006, Chen et al. 2012, Ezechi et al. 2013). Low birth weight-infants and preterm births are 
increasingly recognized as serious, worldwide public health concerns. There is accumulating evidence that LBW among infants is the leading cause of infant morbidity and mortality during the first year of life, subsequently linked to adulthood morbidities (Barker 2007). According to de Mendonça et al. (2020), LBW babies resulting from premature and intrauterine growth restricted (IUGR) babies are major contributors to the growing prevalence of non-communicable diseases, impeding achievement of the global health millennium development goals. To date, the biological mechanisms that lead to LBW babies in HIV-1 positive women on ARV drugs are not well-known, delaying interventional approach to minimize the risks. Furthermore, changes in placental gene expression as a result of placental exposure to HIV-1 and ARV drugs are not well established.

Placenta is the main metabolic, respiratory, excretory, and endocrine organ for the first 9 months of fetal growth in utero. Most of these functions are carried out by the syncytiotrophoblast. Syncytiotrophoblast expresses transporters, growth factor receptors that respond to maternal and fetal factors that regulate complex processes of fetus growth in utero. At molecular level, these growth factors regulate fetal growth through growth factor receptors via intracellular cascades of signaling molecules which are involved in different growth pathways. Insulin-like growth factor (IGF-1) is one of the important growth factor, which facilitate placental angiogenesis, vasculogenesis, protein synthesis and transport of nutrients to the growing fetus. Bioactivities of IGF-1 requires the activation of two important signaling pathways including phosphatidylinositol 5-bisphosphate 3-kinase (PI3K)/protein kinase B (AKT-1) and Ras-mitogen-activated protein kinase (MAP kinase) pathways (Iams and Lovly 2015). The mammalian target for rapamycin (mTOR) is downstream the PI3K/AKT-1 (Forbes and Westwood 2010). It is a master regulator of growth pathways mediated by insulin and insulin-like-growth-factors (IGF)1 , and vascular endothelia growth factors
(VEGF) (Roos et al. 2007, Roos et al. 2009). Studies show that PI3/AKT-1 is important in mediating activities of placental IGF-1 (Sferruzzi-Perri et al. 2011, Forbes and Westwood 2010) including regulating placental transporting activities, cell proliferation, vascularization and hormone synthesis.

HIV-1 infection during pregnancy and use of ARV drugs during pregnancy may change the microenvironment at the intervillous space of the placenta where most maternalfetal and fetal-maternal exchanges occur, affecting fetus growth. Using maternal plasma collected from intervillous-space, Esemu et al. (2019) showed no influence of maternal HIV-1 on maternal plasma levels of IGF-1, angiopoetins, matrix metalloproteases and insulin growth factor binding proteins. However, since the trophoblastic cells of the placenta are permissive to HIV-1 (Fazely et al. 1995, Mognetti et al. 2000, Al-Husaini 2009), studies on the impact of HIV-1 and ARV drugs on expression of placental specific genes critical for fetus and placental growth are important. We therefore investigated changes of placental genes that are important for fetal growth particularly the placental IGF-1, protein kinase B (AKT-1)mTOR, amino acid transporters (Slc38a1, Slc38a2 and Slc38a4) as well as selected antiangiogenic (inhibin A) and angiogenic marker, (adrenomedullin). Understanding gene expression changes in the placenta because of HIV-1 and ARV drug exposure is critical for subsequent design of interventional approach to halt the problem.

\section{Materials and Methods \\ Study population}

A cross sectional study was conducted in two hospitals (Mwananyamala and Mnazi Mmoja) in Dar es Salaam, Tanzania in 2019. Pregnant women consented prior to delivery optimally at 28 weeks of gestation. Inclusion criteria included pregnant women with HIV-1, with age $>18$ years, with and without clinical or severe malaria, that were on or were not on ARV drugs of any combination. Exclusion criteria included chronic helminths infections, multiple births, advanced HIV-1, and 
previous history of preterm birth. The study enrolled fifty-one (51) HIV positive women on ARV drugs and 46 HIV negative women. Using Hulley et al. (2013) formula enrolling 51 HIV-1 positive women provided representative range of pathological condition found in HIV-1 positive placenta in Tanzania.

Ethical approval and consent to participate The study was approved by the Institutional Review Boards of the National Institute of Medical

(NIMR/HQ/R.8A/VOL.IX/2904)

Muhimbili National Hospital (MNH/IRB/I/2019/003). All participants provided written informed consent.

\section{Data and sample collection procedures}

Demographic data were collected using structured interviews and included all clinical data, pregnancy outcomes and information on delivery. Information on parity, length of gestation and HIV-1 status maternal anemia and baby weight were also recorded. The placenta tissue was collected immediately after delivery and maternal tissues removed. The inner most portion of the placenta was then excised into three pieces of about $2 \mathrm{mg}$ and placed in RNA shield (Zymo research) and immediately stored at $-20{ }^{\circ} \mathrm{C}$. Estimated preparation time of placental tissue was $<15$ minutes. Four (4) $\mathrm{ml}$ of intervillous space and peripheral blood was collected and placed in EDTA tubes, plasma collected and immediately frozen at $-20{ }^{\circ} \mathrm{C}$ for two weeks and then transferred to $-80{ }^{\circ} \mathrm{C}$ prior to analysis.

RNA extraction and analysis of gene expression by real time quantitative PCR assay

Extraction of messenger RNA (mRNA) from frozen placenta tissues was done using Quick-
RNA $^{\text {TM }}$ Miniprep Kit following manufacturer's protocol (ZymoR1054, R1055). Quality and yield of RNA were assessed using a NanoDrop UV spectrophotometer. RNA preparations were considered pure when the A260/A280 absorbance ratio was equal to 1.9-2.0. Real time quantitative PCR (RT-qPCR) assays were carried out using NEB Lunar Universal One Step RT-qPCR Kit (New England biolabs) following manufacturer's protocol using SYBR Green detection format in Applied Biosystems 7500 Fast Instrument. Specific sequences of primers used and PCR cycling parameters are indicated in Tables 1 and 2, respectively. Gene expression levels were normalized using an internal control, human GAPDH gene and determined using the $2^{\Delta \Delta \mathrm{Ct}}$ method. To make sure that results are consistent and reproducible, all samples were reverse transcribed in triplicate and repeated twice. Real-time data were analyzed using the Sequence Detector software (Applied Biosystems).

\section{Data analysis}

The data collected were entered in MS-excel sheets. All data analysis was performed using Graph Pad Prism software version 6 . Descriptive data were generated for all variables. Linear regression analysis was done to establish relationships between viral load, relative RNA expression of selected genes and other factors associated with poor pregnancy outcomes. Changes in gene expression in HIV-1 positive samples relative to controls were analyzed using comparative C(T) method (Choi et al. 2011). Controls in this study were placenta of women that were HIV negative and had NBW. The two sample t-test was used to investigate the difference between normalized $\mathrm{C}(\mathrm{T})$. A p- value $<0.05$ was considered significant. 
Kidima et al. - Placental Insulin-Like Growth Factor-1 Receptor, Protein Kinase B and Mammalian Target of Rapamycin ...

\begin{tabular}{|c|c|c|c|}
\hline Gene & Forward ' $5-3$ ' & Reverse '5-3' & References \\
\hline $\begin{array}{l}\text { mTOR/FRAP } \\
1\end{array}$ & CGTGGAGAACATGGATTAGG & GTCCACAGACCAGTGAGGTC & $\begin{array}{l}\text { Afifiyan et al. } \\
\text { (2017) }\end{array}$ \\
\hline INHA & $\begin{array}{l}\text { AGCTCAGACAGCTCTTACCA } \\
\text { CAT }\end{array}$ & $\begin{array}{l}\text { TTCAGCAAATTCTCTTTCTGG } \\
\text { TC }\end{array}$ & $\begin{array}{l}\text { Choi et al. } \\
\text { (2011) }\end{array}$ \\
\hline ADM or AM & $\begin{array}{l}\text { CGG GAT CCA TGA AGC TGG } \\
\text { TTT CCG TC }\end{array}$ & $\begin{array}{l}\text { CGG AAT TCC TAA AGA AAG } \\
\text { TGG GGA GC }\end{array}$ & $\begin{array}{l}\text { Ramachandran } \\
\text { et al. (2009) }\end{array}$ \\
\hline AKT-1 & ATGGAAAGACGTTTTTGTGC & ACCCGCAGGATAGTTTTCTT & $\begin{array}{l}\text { Afifiyan et al. } \\
\text { (2017) }\end{array}$ \\
\hline $\begin{array}{l}\text { Slc38a1 } \\
\text { (SNAT1) }\end{array}$ & $\begin{array}{l}\text { GTGTATGCTTTACCCACCATT } \\
\text { GC }\end{array}$ & $\begin{array}{l}\text { GCACGTTGTCATAGAATGTC } \\
\text { AAGT }\end{array}$ & $\begin{array}{l}\text { Desforges et al. } \\
\text { (2006) }\end{array}$ \\
\hline $\begin{array}{l}\text { Slc38a2(SNAT } \\
\text { 2) }\end{array}$ & $\begin{array}{l}\text { ACGAAACAATAAACACCACC } \\
\text { TTAA }\end{array}$ & $\begin{array}{l}\text { AGATCAGAATTGGCACAGCA } \\
\text { TA }\end{array}$ & $\begin{array}{l}\text { Desforges et al. } \\
\text { (2006) }\end{array}$ \\
\hline $\begin{array}{l}\text { Slc38a4 } \\
\text { (SNAT4) }\end{array}$ & TTGCCGCCCTCTTTGGTTAC & $\begin{array}{l}\text { GAGGACAATGGGCACAGTT } \\
\text { AGT }\end{array}$ & $\begin{array}{l}\text { Desforges et al. } \\
\text { (2006) }\end{array}$ \\
\hline $11 \beta$-HSD-II & $\begin{array}{l}\text { TCAAGACAGAGTCAGTGAGA } \\
\text { AACG }\end{array}$ & GGAACTGCCCATGCAAGTG & $\begin{array}{l}\text { Murphy et al. } \\
\text { (2002) }\end{array}$ \\
\hline GAPDH & CCTGTTCGACAGTCAGCCG & CGACCAAATCCGTTGACTCC & $\begin{array}{l}\text { Sturla et al. } \\
\text { (2009) }\end{array}$ \\
\hline
\end{tabular}

Table 2: PCR cycling parameters

\begin{tabular}{llll}
\hline Cycle Step & Temperature & Time & Cycles \\
\hline Reverse transcription & $55^{\circ} \mathrm{C}^{*}$ & 10 minutes & 1 \\
Initial denaturation & $95^{\circ} \mathrm{C}$ & 1 minute & 1 \\
Denaturation & $95^{\circ} \mathrm{C}$ & 10 seconds & \\
Extension & $60^{\circ} \mathrm{C}$ & 30 seconds**(+plate read) & $40-45$ \\
Melt curve & $60-95^{\circ} \mathrm{C}^{* * *}$ & various & 1 \\
\hline
\end{tabular}

\section{Results}

Characteristics of studied participants

The demographic and clinical characteristics of studied participants are shown in Table 3. Ninety-seven (97) pregnant women attending Mwananyamala Hospital and Mnazi Mmoja Hospital in Dar es Salaam, Tanzania were studied. There were differences in mean age $(\mathrm{p}=0.0016)$ and maternal hemoglobin $(\mathrm{p}>0.001)$ between the HIV-1 positive and negative pregnant women. No difference in mean length of gestation (All, p < 0.0595) existed between the two groups. Majority of infants' weights were in more than 50 percentiles in both HIV-1 positive women ( $\mathrm{p}>0.05$, Table 3$)$. Twenty percent $(20 \%)$ of all delivered babies had LBW. Viral load was detectable in only $10 \%$ of HIV-1 positive pregnant women with viral load ranging from 50-4300 copies/ml (Cobas 8800, Roche Diagnostics).

There was a weaker correlation between duration of ARV drugs uptake and infants' birth weight, but the relationship was not significant $\left(R^{2}=0.041, p>0.05\right.$, Figure 1$)$. Malaria had influence on infants' weight in both HIV-1 positive $(\mathrm{p}>0.0157)$ and negative women $(\mathrm{p}>0.0024$, Unpaired t-test with Welch's correction) (Figure 1). 
Table 3: Demographic and clinical characteristics of studied participants

\begin{tabular}{|c|c|c|c|c|}
\hline & \multicolumn{2}{|l|}{ HIV-1 negative } & \multicolumn{2}{|l|}{ HIV -1 positive } \\
\hline & $\mathbf{N}$ & $\%$ & $\mathbf{N}$ & $\%$ \\
\hline Studied population & 46 & & 51 & \\
\hline Mean age in years & $25.9 \pm 0.8 \mathrm{SEM}$ & & $29.6 \pm 0.9 \mathrm{SEM}$ & $* *$ \\
\hline Primigravidae & 19.0 & 41.3 & 11.0 & 21.6 \\
\hline Secundigravidae & 8.0 & 17.4 & 12.0 & 23.5 \\
\hline Multigravidae & 19.0 & 41.3 & 28.0 & 54.9 \\
\hline $\begin{array}{l}\text { Mean maternal hemoglobin level } \\
(\mathrm{mg} / \mathrm{dl})\end{array}$ & $11.1 \pm 0.2 \mathrm{SEM}$ & & $10.8 \pm 0.2 \mathrm{SEM}$ & $* *$ \\
\hline Mean length of gestation (weeks) & $38.1 \pm 0.5 \mathrm{SEM}$ & & $38.0 \pm 0.4 \mathrm{SEM}$ & \\
\hline Mean placental weight & 0.5 & & 0.5 & \\
\hline Mean infants' weight (kg) & 3.1 & & 2.9 & \\
\hline \multicolumn{5}{|l|}{ Infants' weight percentile } \\
\hline less than $10^{\text {th }}$ percentile (SGA) & 6 & 13.0 & 4 & 7.8 \\
\hline$\geq 10^{\text {th }} \geq 25$ percentile & 3 & 6.5 & 4 & 7.8 \\
\hline$\geq 25 \geq 50$ percentile & 5 & 10.9 & 11 & 21.6 \\
\hline$\geq 50 \leq 75$ percentile & 9 & 19.6 & 9 & 17.6 \\
\hline$>75$ percentile & 23 & 50.0 & 22 & 43.1 \\
\hline $\begin{array}{l}\text { Low birth weight babies }(\geq 2.5 \\
\mathrm{kg})\end{array}$ & 9 & 19.6 & 11 & 21.6 \\
\hline Normal birth weight & 39 & 84.8 & 45 & 88.2 \\
\hline $\begin{array}{l}\text { Peripheral malaria positivity by } \\
\text { mRDT }\end{array}$ & 5 & 10.9 & 6 & 11.8 \\
\hline $\begin{array}{l}\text { Soil transmitted helminths } \\
\text { infections }\end{array}$ & 4 & 8.7 & 3 & 5.9 \\
\hline Folic acid use & 41 & 89.1 & 46 & 90.2 \\
\hline ARV drug use & - & - & 51 & 100.0 \\
\hline Less than a year & & & 7 & 14 \\
\hline 1 to 2 years & & & 23 & 45 \\
\hline 3 years and above & & & 21 & 41 \\
\hline Alcohol uptake & 4 & 8.7 & 7 & 13.7 \\
\hline
\end{tabular}

\footnotetext{
*Indicate level of significant different.
} 
A)

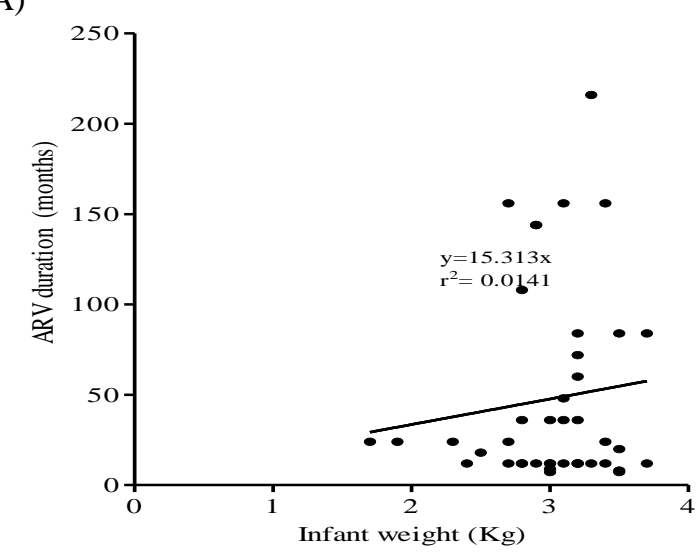

B)

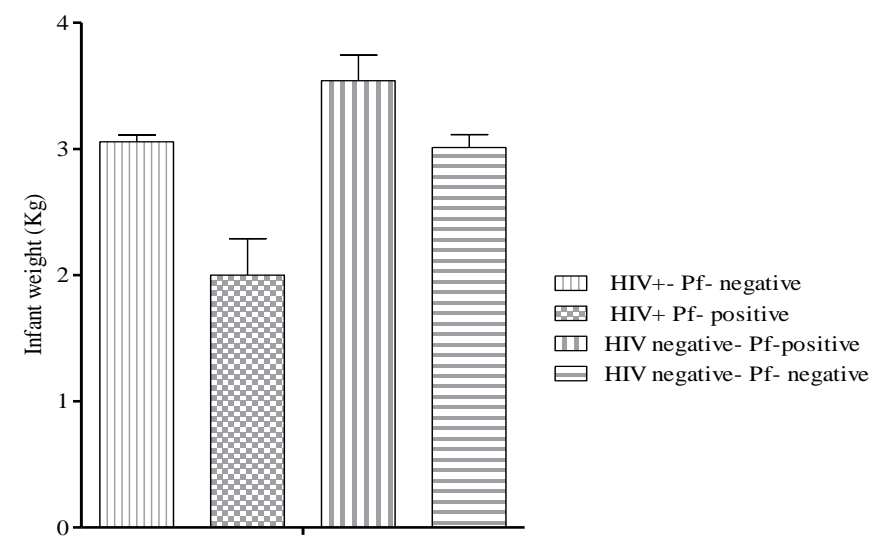

Malaria status

Figure 1: Relationships between A) duration of ARV drugs uptake, B) peripheral malaria with infant weight.

mRNA expression of placental IGF-1R, mTOR, and protein Kinase B (AKT-1)

mRNA expression of IGF-1R was downregulated in placentas of HIV-1 positive women compared to control (HIV negative with NBW) (t-test $\mathrm{p}<0.0001)$. The IGF-1R mRNA levels were 3 and more than 40 folds lower in placentas of women delivering LBW babies in placenta of HIV-1 negative and positive women, respectively ( $\mathrm{t}$-test $\mathrm{p}<$ 0.0001 , Figure 2). The mRNA of AKT-1 was significantly upregulated in placenta of HIV negative women delivering LBW babies; demonstrating 60-fold increase in mRNA expression (t-test $\mathrm{p}<0.000$ ) and downregulated in HIV-1 positive placentas (1.6 and 2.2 folds in LBW and NBW, respectively, all $\mathrm{p}<0.0001$ ).

Similarly, the mRNA expression of mTOR was lower in placentas of all HIV positive women (t-test, $\mathrm{p}<0.0001$ ). Surprisingly, the mTOR mRNA level was significantly upregulated in placenta of women that were HIV-1 negative delivering LBW babies (t-test, $\mathrm{p}<0.0001$, Figure 2). 
A)

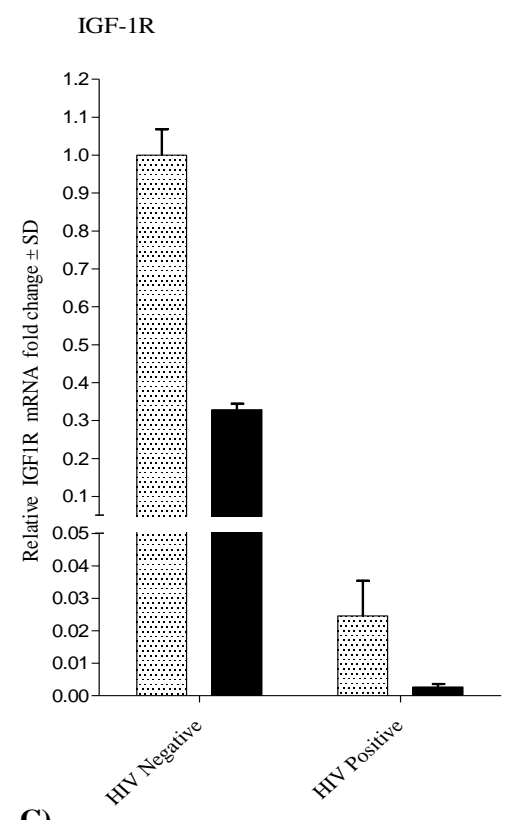

C)

AKT 1

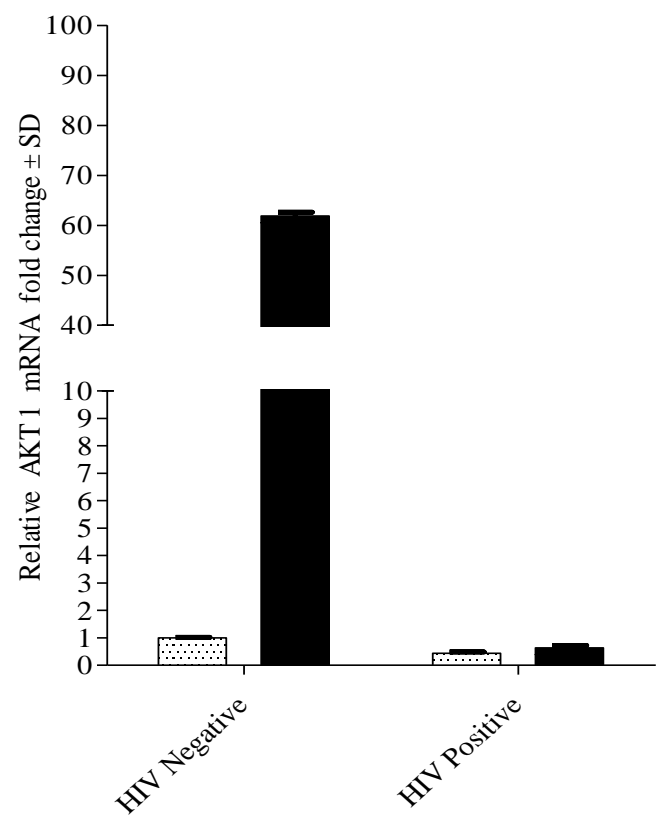

B)

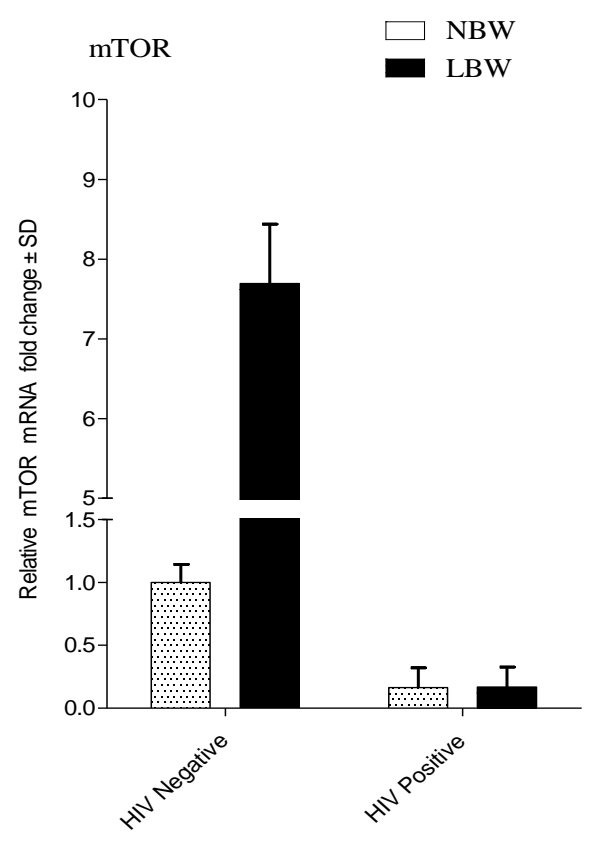

Figure 2: Fold change in the mRNA expression ( \pm SD) of A) IGF-1R, B) mTOR and C) AKT1 in placental from pregnant women with HIV-1 and without HIV-1. Fold change in mRNA expression is relative to HIV-1 negative placentas with Normal Birth Weight (control). 
Messenger RNA expression of placental amino acids transporters

Placental Slc38a1 and Slc38a2 mRNA expression levels were significantly upregulated in placentas of women with LBW babies from both HIV-1 positive and negative placentas (t-test, all $\mathrm{p}<0.0001$ ), with an increase in the mRNA expression levels ranging from 30 to more than 100 folds in Slc38a1 and Slca38a2 in HIV-1 negative positive women delivering LBW babies compared to control (Figure 3).
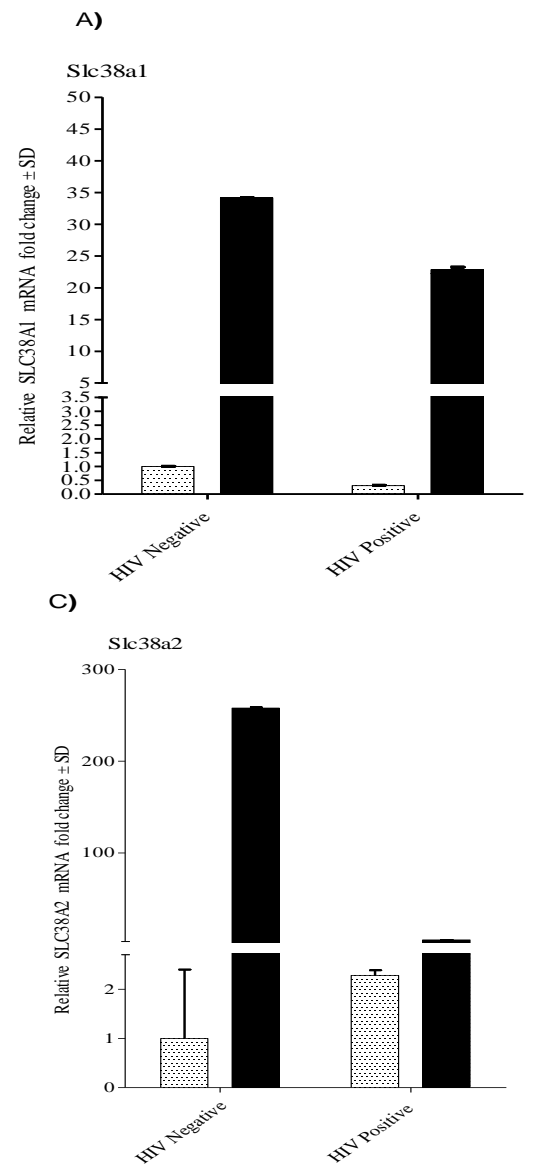

Messenger RNA expression of placental adrenomedullin and inhibin $A$

The mRNA of placental inhibin A was upregulated in HIV-1 positive placentas delivering LBW (t-test, $\mathrm{p}<0.0001$ ). However, the mRNA levels of placental inhibin A decreased by 12 folds in HIV-1 negative placentas with LBW babies (Figure 3 ) and by 2 folds in HIV positive placenta with NBW babies (Figure 4). In this study, placental ADM mRNA levels decreased by 50 folds in HIV-1 placentas with both NBW and LBW babies and by only 2 folds in HIV negative women with LBW compared to the control (Figure 4).

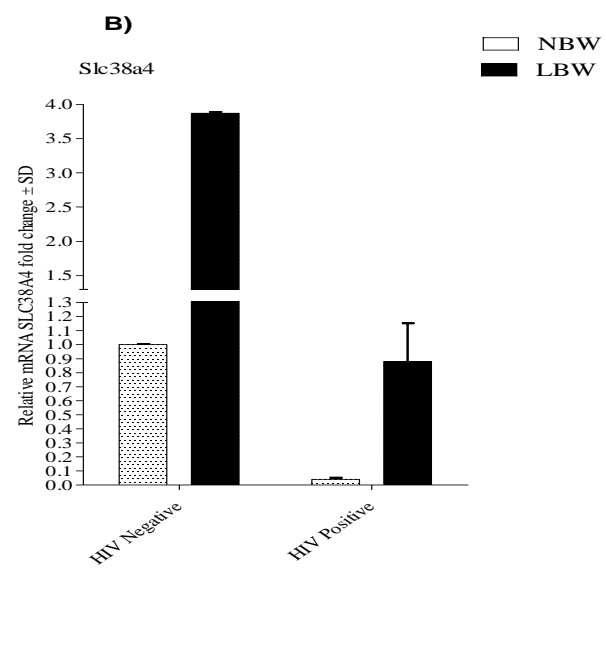

Figure 3: Fold change in mRNA expression ( \pm SD) of A) Slc38a1, B) Slc38a1 and C) Slc38a1 in placental from pregnant women with HIV-1 and without HIV-1. Fold change in mRNA expression is relative to HIV-1 negative placentas with Normal Birth Weight (control). 
A)

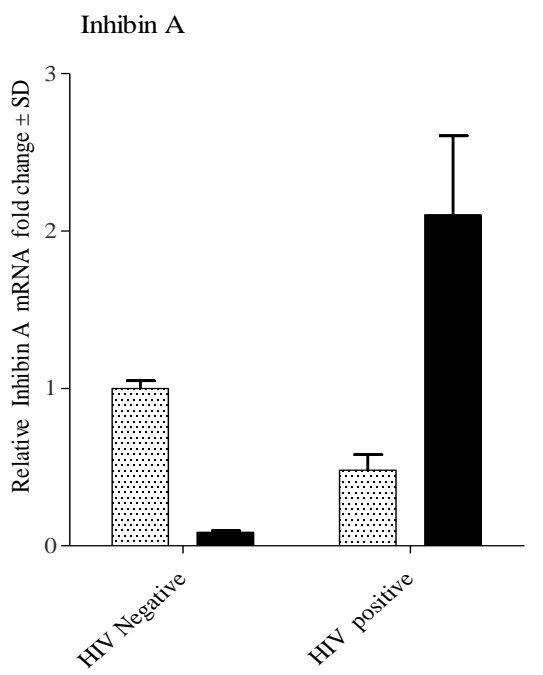

B)

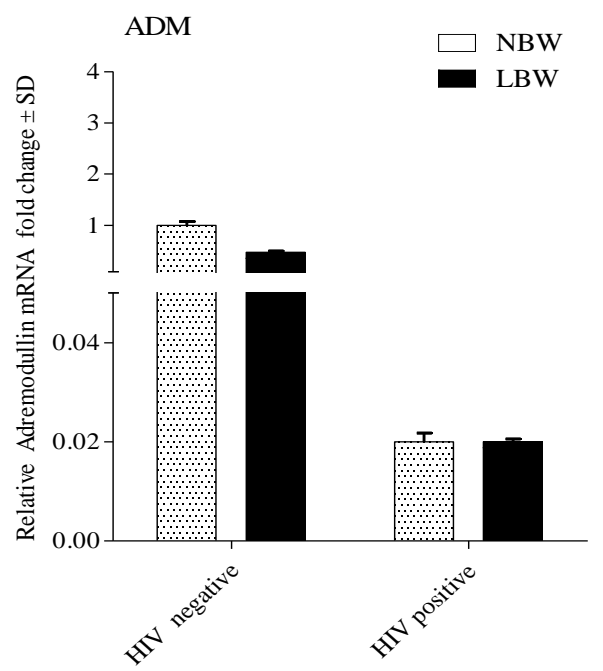

Figure 4: Fold change in the mRNA expression ( \pm SD) of $\mathbf{A}$ ) inhibin A and $\mathbf{B}$ ) adrenomedullin in placental cells from pregnant women with HIV-1 and without HIV-1. Fold change in mRNA expression is relative to HIV-1 negative placentas with Normal Birth Weight (control).

Messenger RNA expression of placental 11ß-hydroxysteroid dehydrogenase In this study, women delivering LBW babies demonstrated high levels of $11 \beta$-HSD-2 mRNA expression in both HIV-1 negative and positive women compared to the control (t-test, all p $<0.0001$, Figure 5), with HIV-1 negative placentas from women with LBW babies expressing significantly higher levels of $11 \beta-H S D-2$ mRNA compared to the placentas of HIV-1 positive women delivering LBW babies ( $\mathrm{p}<0.05)$.

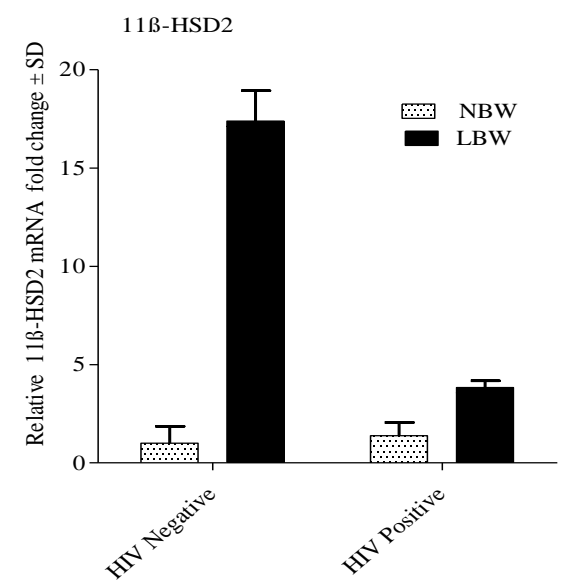

Figure 5: Fold change in mRNA expression $( \pm \mathrm{SD})$ of $11 \beta$-HSD-2 in placentas from pregnant women with HIV-1 and without HIV-1. Fold change in mRNA expression is relative to HIV-1 negative placentas with Normal Birth Weight (control). 


\section{Discussion}

We investigated the influence of HIV-1 and ARV drugs on expression of selected genes coding for proteins involved in the IGF-1 growth pathway, stress response, angiand anti-angiogenic factors. It was found that mRNA levels of placental IGF-1R, AKT-1, mTOR and ADM are downregulated in HIV1 positive women regardless of the baby's weight. However, HIV-1 positive women delivering LBW babies had higher mRNA level of an antiangiogenic molecule, the inhibin A. Genes coding for placental systemA amino acid transporters (Slc38a1, Slc38a2) were upregulated in both HIV-1 positive and negative women with LBW babies. Surprisingly, mRNA expression of placental inhibin A was downregulated in placentas of HIV-1 negative women with LBW babies. The differential gene expression observed in placentas of HIV-1 positive and negative women suggest placental responses to different intervillous space microenvironments.

The dramatic decrease in IGF-1R expression in HIV-1 positive placentas in this study may be a result of changes in maternal fetal microenvironment associated with HIV1 infections and ARV drugs uptake. Lower placental mRNA IGF-1R expression may result into decrease in IGF-1R protein expression affecting placental-specific IGF-1 axis activities, which are critical for placenta and fetus growth (Sferruzzi-Perri et al. 2017). Studies showed that activation of placental IGF-1R by IGF-1 stimulates system-A amino acid and glucose uptake, facilitating placental vascularization and proliferation leading to proper placental development and function (Brett et al. 2014, Sferruzzi-Perri et al. 2017). It could conceivably be hypothesised that placental exposure to HIV-1 and ARV drugs may induce epigenetic changes that affect transcription of certain genes in the placenta similar to the observations by Chandel et al. (2013) and Shiau et al. (2019) in immune cells of HIV-1 infected hosts. Understanding global placental epigenetic changes in HIV-1 and/or ARV drugs exposed placentas is important considering that the placental syncytiotrophoblast are also permissive to HIV-1.

Numerous evidence show that placental mTOR is dysregulated in various causes of FGR (Roos et al. 2007) including placental malaria-mediated (Boeuf et al. 2013) and in idiopathic FGR (Scifres and Nelson 2009). Surprisingly, the relative mRNAs expression for placental mTOR and AKT-1 in the current study was higher in placentas of HIV-1 negative women delivering LBW babies. Upregulation of mTOR and AKT-1 in placentas of HIV-1 negative women suggest existence of physiological adaption in this group. Adaptive responses have been reported previously by Aiko et al. (2014) in which placental mTOR protein was shown to increase in placental of women delivering LBW babies and in those with preeclampsia (Desforges et al. 2006). Placental adaptive responses are important in maintaining fetus development (Myatt 2006). Contrary to HIV negative women, mTOR and AKT-1 mRNA levels were downregulated in placentas of HIV positive women. Evidence shows that HIV-1 virus though its matric protein P17 activates PI3K/AKT-1 pathway in HIV-1 infected cells including human macrophages (Giagulli et al. 2011). The activation of PI3K in target cells occurs by inhibiting the phosphatase and tensin homolog (PTEN), which is the potent inhibitor of the PI3K/AKT-1 signaling pathway. We surmise that the HIV-1viral suppression by the ARV drugs among the $90 \%$ of the pregnant women in the current study might have led to an increased level of PI3K/AKT-1 inhibitor (PTEN) in placental cells leading to downregulation of placenta AKT-1 and consequently the mTOR. Further studies need to be carried out in order to investigate influence of HIV-1 and ARV drugs on growth signaling pathways other than the IGF-1RPI3K /AKT-1-mTOR.

According to Cleal et al. (2018), placental protein synthesis reduces the pool of amino acids available for transport across the placenta by the accumulative transporters, the Scl38a1, 2 and 4. Accordingly, a decrease in mTOR expression in HIV-1 infected placentas delivering LBW babies in this study 
might have reduced protein synthesis of the placenta (Wang and Proud 2006). Reduced protein synthesis as a result of reduced mTOR gene expression in placentas of HIV-1 positive women delivering LBW might have triggered increase in expression of amino acid transporters to cater for scarcity of amino acid transport across the placenta. The upregulation of Slc38a1 and Slca38a2 mRNAs in HIV-1 positive women delivering LBW babies may also suggest placental adaptive immune responses to a decreased amino acid pool in the placenta. However, to fully understand the influence of HIV-1 and ARV drugs on placental expression of amino acid transporters, a multivariate analysis is needed to be done controlling for maternal nutritional diet, the major determinant of resources and other important environmental factors, which is beyond the scope of this study.

Although the placenta is the principal metabolic, respiratory, excretory, and endocrine organ for the first 9 months of fetal growth in utero, it is not innervated (Marzioni et al. 2004). Consequently, local expression of placental vasodilators, vasoconstrictors as well as angiogenic factors are essential in maintaining vascular tone during pregnancy for optimal transport of nutrient and gases for placental and fetal growth. Evidence suggests imbalance between placental pro-angiogenic and antiangiogenic proteins is the most important factor affecting nutrients transport from the placenta to the fetus (Ilekis et al. 2016). Inhibin A is an antiangiogenic molecule that is produced by the fetoplacental unit throughout gestation (Shen et al. 2011). Increased placental inhibin A expression has been identified as a major contributing factor to the placental dysfunction leading to premature delivery and fetal growth restriction (Reddy et al. 2009, Shen et al. 2011). Furthermore, Singnoi et al. (2019) demonstrated negative influence of high maternal serum inhibin A on normal placentation. Higher levels of placental inhibin A in HIV-1 positive women with LBW babies in the current study may have induced poor formation of blood vessels leading to poor placental perfusion and therefore LBW babies. This is in contrary to what was observed in HIV-1 negative women delivering LBW babies. Despite the current observations, several questions remain unanswered at present; First, are lower placental inhibin A mRNA expression levels among the HIV-1 negative women delivering LBW babies specific adaptive responses against anti-angiogenesis in placentas of women in this group? Second, are inhibin A mRNA levels a major determinant of birth weight among HIV-1 women that are on ARVs? Future investigations are needed to assess factors influencing levels of placental inhibin A in HIV-1 positive and negative women delivering LWB and NBW, their roles in villous placental angiogenesis and potential use as an antiangiogenic marker.

Contrary to inhibin A, adrenomedullin is known to stimulate the growth of new blood vessels and increase the cells tolerance to hypoxic injury and oxidative stress (Moriyama et al. 2001). Evidence suggests that ADM expression is an important factor for successful implantation and maintenance of placental vascular tone and development (Lenhart and Caron 2012). Using knockout mice, Li et al. (2006) showed that genetical reduction of $\mathrm{ADM}$ expression in mice affected liter size and general placental development. Therefore, lower mRNA levels of ADM among HIV-1 positive placentas suggest potential disruption of placental vascular tone in HIV-1 positive women.

\section{Conclusion}

This current study clearly indicated HIV-1 and ARV drugs induce differential placental gene expression. The IGF-1-P13/AKT-1mTOR signaling pathway is dysregulated among HIV-1 positive women on ARV drugs. In addition, there were higher mRNA expression of an antiangiogenic molecule (inhibin A) and lower expression of angiogenic molecule (ADM) in placentas of HIV-1 positive women delivering LBW babies. These results suggest that ARV drugs and HIV-1 may be involved in the disruption of vascular tone of the placenta, and therefore placental perfusion. Multivariate analyses to investigate the roles of other environmental 
factors in placental expression of genes involved in fetal growth are critical to determine other determinants of delivering LBW babies. In addition, we recommend further studies to investigate placental growth pathways other than the IGF-1-AKT-1mTOR.

Consent for Publication: All authors read and approved the manuscript.

Competing interests: Authors declare no conflict of interest.

Funding: This work was supported by University of Dar es Salaam Research Funds Grant No. CoNAS-ZLW18033.

\section{Acknowledgements}

We thank the registered nurses in the Department of Obstetrics and Gynecology Mwananyamala Hospital and Mnazi Mmoja Hospital, particularly Mr Harry Zachariah, Moses Kilenza and Elibariki Mauki. We also thank Mr. Bishop Ignas Magidanga from the Centre for Infectious Diseases \& Biotechnology for assistance in the laboratory works.

\section{References}

Afifiyan N, Tillman B, French BA, Masouminia M, Samadzadeh S and French SW 2017 Over expression of proteins that alter the intracellular signaling pathways in the cytoplasm of the liver cells forming Mallory-Denk bodies. Exp. Mol. Pathol. 102(1): 106-114.

Aiko Y, Askew DJ, Aramaki S, Myoga M, Tomonaga C, Hachisuga T, Suga R, Kawamoto T, Tsuji M and Shibata E 2014 Differential levels of amino acid transporters system L and ASCT2, and the mTOR protein in placenta of preeclampsia and IUGR. BMC Pregnancy Childbirth 14: 181.

Al-Husaini AM 2009 Role of placenta in the vertical transmission of human immunodeficiency virus. J. Perinatol. 29(5): 331-336.

Barker DJ 2007 The origins of the developmental origins theory. J. Intern. Med. 261(5): 412-417.

Brett KE, Ferraro ZM, Yockell-Lelievre J, Gruslin A and Adamo KB 2014 Maternal- fetal nutrient transport in pregnancy pathologies: the role of the placenta. Int. J. Mol. Sci. 15(9): 16153-16185.

Brocklehurst $\mathrm{P}$ and French R 1998 The association between maternal HIV infection and perinatal outcome: a systematic review of the literature and meta-analysis. $\mathrm{Br} . J$. Obstet. Gynaecol. 105(8): 836-848.

Boeuf P, Aitken EH, Chandrasiri U, Chua CL, McInerney B, McQuade L, Duffy M, Molyneux M, Brown G, Glazier $\mathrm{J}$ and Rogerson SJ 2013 Plasmodium falciparum malaria elicits inflammatory responses that dysregulate placental amino acid transport. PLoS Pathog. 9(2): e1003153.

Chandel N, Husain M, Goel H, Salhan D, Lan X, Malhotra A, McGowan J and Singhal PC 2013 VDR hypermethylation and HIVinduced T cell loss. J. Leukocyte Biol. 93(4): 623-631.

Chen JY, Ribaudo HJ, Souda S, Parekh N, Ogwu A, Lockman S, Powis K, DrydenPeterson S, Creek T, Jimbo W, Madidimalo T, Makhema J, Essex M and Shapiro RL 2012 Highly active antiretroviral therapy and adverse birth outcomes among HIVinfected women in Botswana. J. Infect. Dis. 206(11): 1695-1705.

Choi YG, Seok YH, Yeo S, Jeong MY and Lim S 2011 Protective changes of inflammationrelated gene expression by the leaves of Eriobotrya japonica in the LPS-stimulated human gingival fibroblast: microarray analysis. J. Ethnopharmacol. 135(3): 636645.

Cleal JK, Lofthouse EM, Sengers BG and Lewis RM 2018 A systems perspective on placental amino acid transport. J. Physiol. 596(23): 5511-5522.

de Mendonça ELSS, de Lima Macêna M, Bueno NB, de Oliveira ACM, Mello CS 2020 Premature birth, low birth weight, small for gestational age and chronic noncommunicable diseases in adult life: A systematic review with meta-analysis. Early Hum. Dev. 149: 105154.

Desforges M, Lacey HA, Glazier JD, Greenwood SL, Mynett KJ, Speake PF and Sibley CP 2006 SNAT4 isoform of system A amino acid transporter is expressed in human placenta. Am. J. Physiol.: Cell Physiol. 290(1): C305-C312.

Esemu LF, Yuosembom EK, Fang R, Rasay S, Fodjo BAY, Nguasong JT, Kidima W, Ekali 
GL, Chen JJ, Ndhlovu L, Bigoga JD, Taylor DW, Leke RGF and Babakhanyan A 2019 Impact of HIV-1 infection on the IGF-1 axis and angiogenic factors in pregnant Cameroonian women receiving antiretroviral therapy. PLoS One 14(5): e0215825.

Ezechi OC, Gab-Okafor CV, Oladele DA, Kalejaiye OO, Oke BO, Ohwodo HO, Adu RA, Ekama SO, Musa Z, Onwujekwe DI, David AN, and Ujah IAO 2013 Pregnancy, Obstetric and Neonatal Outcomes in HIV Positive Nigerian Women. Afr. J. Reprod. Health 17(3): 160-168.

Fazely F, Fry GN, Thirkill TL, Hakim H, King BF and Douglas GC 1995 Kinetics of HIV infection of human placental syncytiotrophoblast cultures: an ultrastructural and immunocytochemical study. AIDS Res. Hum. Retroviruses. 11(9): 1023-1030.

Forbes K and Westwood M 2010 Maternal growth factor regulation of human placental development and fetal growth. $J$. Endocrinol. 207(1): 1-16.

Giagulli C, Marsico S, Magiera AK, Bruno R, Caccuri $\mathrm{F}$, Barone I, Fiorentini $\mathrm{S}$, Andò $\mathrm{S}$ and Caruso A 2011 Opposite effects of HIV1 p17 variants on PTEN activation and cell growth in B cells. PLoS One 6(3): e17831.

Goldenberg RL, Mudenda V, Read JS, Brown ER, Sinkala M, Kamiza S, Martinson F, Kaaya E, Hoffman I, Fawzi W, Valentine M, Taha TE; HPTN 024 Study Team 2006 HPTN 024 study: histologic chorioamnionitis, antibiotics and adverse infant outcomes in a predominantly HIV-1infected African population. Am. J. Obstet. Gynecol. 195(4): 1065-1074.

Hulley SB, Cummings SR, Browner WS, Grady DG and Newman TB 2013 Designing clinical research: an epidemiologic approach, $4^{\text {th }}$ ed, Wolters Kluwer/Lippincott Williams and Wilkins, Philadelphia, PA.

Iams WT and Lovly CM 2015 Molecular pathways: Clinical applications and future direction of insulin-like growth factor-1 receptor pathway blockade. Clin. Cancer Res. 21(19): 4270-4277.

Ilekis JV, Tsilou E, Fisher S, Abrahams VM, Soares MJ, Cross JC, Zamudio S, Illsley NP, Myatt L, Colvis C, Costantine MM, Haas DM, Sadovsky Y, Weiner C, Rytting E and Bidwell G 2016 Placental origins of adverse pregnancy outcomes: potential molecular targets: An Executive Workshop Summary of the Eunice Kennedy Shriver National Institute of Child Health and Human Development. Am. J. Obstet. Gynecol. 215(1): S1-S46.

Lenhart PM and Caron KM 2012 Adrenomedullin and pregnancy: perspectives from animal models to humans. Trends Endocrinol. Metab. 23(10): 524-532.

Li M, Yee D, Magnuson TR, Smithies O and Caron KM 2006 Reduced maternal expression of adrenomedullin disrupts fertility, placentation, and fetal growth in mice. J. Clin. Invest. 116(10): 2653-2662.

Marzioni D, Tamagnone L, Capparuccia L, Marchini C, Amici A, Todros T, Bischof P, Neidhart S, Grenningloh $G$ and Castellucci M 2004 Restricted innervation of uterus and placenta during pregnancy: evidence for a role of the repelling signal Semaphorin 3A. Dev. Dyn. 231(4): 839-848.

Mognetti B, Moussa M, Croitoru J, Menu E, Dormont D, Roques P, Chaouat G 2000 HIV-1 co-receptor expression on trophoblastic cells from early placentas and permissivity to infection by several HIV-1 primary isolates. Clin. Exp. Immunol. 119(3): 486-492.

Moriyama T, Otani T and Maruo T 2001 Expression of adrenomedullin by human placental cytotrophoblasts and choriocarcinoma JAr cells. J. Clin. Endocrinol. Metab. 86(8): 3958-3961.

Murphy VE, Zakar T, Smith R, Giles WB, Gibson PG and Clifton VL 2002 Reduced 11beta-hydroxysteroid dehydrogenase type 2 activity is associated with decreased birth weight centile in pregnancies complicated by asthma. J. Clin. Endocrinol. Metab. 87(4): 1660-1668.

Myatt L 2006 Placental adaptive responses and fetal programming. J. Physiol. 572(Pt 1): 2530.

Ramachandran V, Arumugam T, Langley R, Hwang RF, Vivas-Mejia P, Sood AK, Lopez-Berestein G and Logsdon CD 2009 The ADMR receptor mediates the effects of adrenomedullin on pancreatic cancer cells and on cells of the tumor microenvironment. PLoS One 4(10): e7502.

Reddy A, Suri S, Sargent IL, Redman CWG and Muttukrishna S 2009 Maternal circulating levels of activin A, inhibin A, sFlt-1 and 
endoglin at parturition in normal pregnancy and pre-eclampsia. PLoS One 4(2): e4453.

Roos S, Jansson N, Palmberg I, Säljö K, Powell TL and Jansson T 2007 Mammalian target of rapamycin in the human placenta regulates leucine transport and is downregulated in restricted fetal growth. $J$. Physiol. 582(1): 449-459.

Roos S, Powell TL and Jansson T 2009 Placental mTOR links maternal nutrient availability to fetal growth. Biochem. Soc. Trans. 37(1): 295-298.

Scifres CM and Nelson DM 2009 Intrauterine growth restriction, human placental development and trophoblast cell death. $J$. Physiol. 587(14): 3453-3458.

Sferruzzi-Perri AN, Owens JA, Pringle KG and Roberts CT 2011 The neglected role of insulin-like growth factors in the maternal circulation regulating fetal growth. $J$. Physiol. 589(1): 7-20.

Sferruzzi-Perri AN, Sandovici I, Constancia M and Fowden AL 2017 Placental phenotype and the insulin-like growth factors: resource allocation to fetal growth. J. Physiol. 595(15): 5057-5093.

Shiau S, Strehlau R, Wang S, Violari A, Do C, Patel F, Liberty A, Krupska I, Arpadi SM,
Foca M, Coovadia A, Abrams EJ, Tycko B, Terry MB and Kuhn L 2019 Distinct epigenetic profiles in children with perinatally-acquired HIV on antiretroviral therapy. Sci. Rep. 9(1): 10495.

Shen Z, Cai LY, Suprapto IS, Shenoy P and Zhou X 2011 Placental and maternal serum inhibin A in patients with preeclampsia and small-for-gestational-age. J. Obstet. Gynaecol. Res. 37(10): 1290-1296.

Singnoi W, Wanapirak C, Sekararithi R and Tongsong T 2019 A cohort study of the association between maternal serum InhibinA and adverse pregnancy outcomes: a population-based study. BMC Pregnancy Childbirth 19(1): 124, 7 pages.

Sturla L, Fresia C, Guida L, Bruzzone S, Scarfi S, Usai C, Fruscione F, Magnone M, Millo E, Basile G, Grozio A, Jacchetti E, Allegretti M, De Flora A and Zocchi E 2009 LANCL2 is necessary for abscisic acid binding and signaling in human granulocytes and in rat insulinoma cells. J. Biol. Chem. 284(41): 28045-28057.

Wang X and Proud CG 2006 The mTOR pathway in the control of protein synthesis. Physiology (Bethesda) 21: 362-369. 